\title{
The pattern of proteins and of peptide hydrolase activities in shoots of field-grown winter wheat during the cold season
}

\author{
A Fischer, U Feller * \\ Institute of Plant Physiology, University of Bern, Altenbergrain 21, CH-3013 Bern, Switzerland
}

(Received 12 October 1992; accepted 6 January 1993)

\begin{abstract}
Summary - Winter cereals in the field are subject to low temperatures during an early stage of vegetative growth. Metabolic activities are low during this period. The quantities of enzymes involved in nitrogen assimilation, carbon assimilation and photorespiration were analyzed by gel electrophoresis and immunoblotting. The levels of all enzymes studied were well maintained throughout the winter, even during 2 marked low-temperature phases. The activities of various peptide hydrolases were measured in the same samples. The major endopeptidase activity at pH 5.0 remained relatively constant during the winter, while aminopeptidase and carboxypeptidase activities increased during a warmer phase at the beginning of January. The maintenance of important assimilatory enzymes during the period of low metabolic activity may allow a rapid restart of growth in spring.
\end{abstract}

Triticum aestivum L / low temperature / assimilatory enzyme / peptide hydrolase / proteolysis

Résumé - Distribution des protéines et des activités des hydrolases peptidiques dans les parties aériennes de blé d'hiver cultivé en champ durant la saison froide. Dans les champs, les céréales d'hiver sont sujettes à de basses températures à un stade précoce de leur croissance végétative. Les activités métaboliques sont faibles durant cette période. Les taux d'enzymes impliquées dans l'assimilation de l'azote et du carbone, ainsi que dans la photorespiration, ont été analysés par électrophorèse sur gel et par des techniques immunologiques. Les taux de ces enzymes ont été bien maintenus, et cela même lors de 2 phases marquées de basses températures. Les activités de différentes protéases ont été mesurées sur les mêmes échantillons. L'activité endopeptidasique principale (mesurée à $\mathrm{pH} 5,0$ ) est restée relativement constante pendant tout l'hiver, alors que les activités amino- et carboxypeptidasiques ont augmenté durant une période plus chaude située au début du mois de janvier. La maintenance d'enzymes assimilatrices importantes durant les périodes de faible activité métabolique semble permettre une reprise rapide de la croissance au printemps.

Triticum aestivum L / basse température / enzyme assimilatrice / hydrolase peptidique / protéolyse

\section{INTRODUCTION}

Winter cereals are subject to extreme conditions during the cold period of the year in temperate and northern zones. Low temperatures or freeze-thaw cycles can lead to the dissociation and inactivation of cold-labile enzymes from different plant species (Guy, 1990). In laboratory experiments with potato it was shown that the cooling rate is an important factor for the damage caused in different cellular functions (Steffen et al, 1989). Extracellular freezing leads to the desiccation of the protoplast, resulting in higher solute concentrations (Guy, 1990), and encasement of the whole plant in ice under reduced light intensities can lead to hypoxic conditions, causing difficulties in energy metabolism (Andrews and Pomeroy, 1989). It is still unclear to what extent the assimilatory infrastructure is maintained in winter cereals during the cold season.

\footnotetext{
* Correspondence and reprints
} 
Altered gene expression and protein synthesis during the treatment of tolerant and intolerant plants with low temperatures have been investigated by several research groups (Cloutier, 1983; Schaffer and Fischer, 1988; Guy and Haskell, 1989; Perras and Sarhan, 1989; Houde et al, 1992; Neven et al, 1992). However, protein catabolism and proteolytic activities have rarely been considered in this context. A dissociation into subunits may increase the accessibility of proteins for proteolytic degradation. Several enzymes have been shown to be stabilized by low molecular weight compounds (Feller, 1986; Chen and Spreitzer, 1991; Fischer et al, 1992). Intracellular concentrations of such effectors might be influenced by extracellular freezing or by altered fluxes through a metabolic pathway after inactivation of a cold-labile enzyme. Schaffer and Fischer (1988) reported an enhanced expression of a gene coding for a thiol protease during chilling of unripe tomato fruits and discussed a possible role of such a protein in the degradation of cold-damaged polypeptides. Perras and Sarhan (1989) reported that the intensities of some bands on SDS-PAGE gels decreased during cold acclimation of winter wheat, while other bands became more intense.

Considering the facts mentioned above, 2 strategies are possible for winter cereals during the cold season. On the one hand, the quantity of enzymes involved in assimilatory processes might be lowered during the phase of reduced metabolism, and as a consequence their resynthesis would be necessary prior to the restart of rapid growth. On the other hand, the maintenance of the assimilatory infrastructure could be beneficial in allowing an immediate response to elevated temperatures following the cold period. Some enzymes involved in carbon and nitrogen assimilation have been found to be rather susceptible to proteolysis in wheat leaf extracts (Feller, 1986), in isolated pea chloroplasts (Mitsuhashi and Feller, 1992) and in attached wheat leaves after interrupting the phloem (Fröhlich and Feller, 1991). Endopeptidase activities are in general higher during a net degradation of proteins, while aminopeptidase activities decrease during such phases (Feller, 1986). Such changes in anabolic and catabolic capacities during a cold period may affect the vigour of the plants and influence their development afterwards. The aim of the work presented here was to detect changes in the activities of selected peptide hydrolases and to elucidate the fate of some important enzymes involved in nitrogen assimilation, carbon assimilation and photorespiration in winter wheat during low-temperature phases in the field.

\section{MATERIALS AND METHODS}

\section{Plant material}

Winter wheat plants (Triticum aestivum L cv Arina) were grown in a field near Bern. Whole plants were cut every 2 weeks directly above the soil surface and transported to the laboratory on ice. Extracts were prepared immediately from the fresh plant material.

\section{Extraction}

The extraction medium contained $20 \mathrm{mM}$ sodium phosphate buffer $\mathrm{pH} 7.5,1 \%(\mathrm{w} / \mathrm{v})$ polyvinylpolypyrrolidone and $0.1 \%(v / v) \beta$-mercaptoethanol. Ten wheat plants were homogenized in $10 \mathrm{ml}$ extraction buffer with a Polytron mixer (Kinematica, Littau/Luzern) for $20 \mathrm{~s}$ at medium speed and for $5 \mathrm{~s}$ at full speed. Larger volumes of extraction medium were used after the restart of growth in spring $(15 \mathrm{ml} / 10$ plants on March 6 , $30 \mathrm{ml} / 10$ plants on march 20). The crude extracts were filtered through Miracloth (Calbiochem, San Diego, CA)

\section{Proteins and chlorophylls}

Chlorophyll was measured according to Strain et al (1971). The filtrate through Miracloth was mixed with acetone (final concentration $80 \%$ ) and centrifuged $(5$ $\mathrm{min}$ at $2300 \mathrm{~g}$ ) before photometry at 649 and 665 $\mathrm{nm}$. Total proteins (filtrate through Miracloth) and soluble proteins (supernatants after centrifugation for 15 min at $12000 \mathrm{~g}$ ) were determined according to Bradford (1976). Bovine $\gamma$-globulin was used as standard.

\section{Carbohydrates and free amino groups}

Supernatants of extracts centrifuged for $10 \mathrm{~min}$ at 2300 $\mathrm{g}$ were stored frozen $\left(-20^{\circ} \mathrm{C}\right)$ for these measurements. Soluble carbohydrates were quantified according to Fluri (1959) with some modifications as described by Fröhlich and Feller (1991). Free amino groups were detected with a ninhydrin reagent (Cramer, 1958).

\section{Peptide hydrolase activity}

Freshly-prepared extracts centrifuged for $10 \mathrm{~min}$ at $2300 \mathrm{~g}$ were used for these measurements. Amino- 
peptidase activity was detected in microtitration plates using the method described previously (Blättler and Feller, 1988). L-Amino acid-p-nitroanilides (final concentration in the substrate solution : $1 \mathrm{mM}$ ) were dissolved in dimethylsulfoxide (final concentration: $2 \%$ $\mathrm{v} / \mathrm{v}$ ) and then mixed with buffer $(100 \mathrm{mM}$ Bis-Tris propane and $50 \mathrm{mM}$ sodium acetate adjusted to the desired $\mathrm{pH}$ value with $\mathrm{HCl}$ ). Hydrolysis of the different substrates was measured at slightly different $\mathrm{pH}$ values, according to the optima determined in a preliminary experiment. Carboxypeptidase activity was detected in microtitration plates according to Salgó and Feller (1987) using the $N$-masked dipeptide $\mathrm{N}$-carbobenzoxy-L-phenylalanine-L-alanine as substrate. Endopeptidase activity was detected according to Fröhlich and Feller (1992) using azocasein as substrate. Because of interferences at neutral and alkaline $\mathrm{pH}$ values, all extracts prepared on January 9th onwards for endopeptidase measurements were desalted by centrifugation through Sephadex G-25 (Feller et al, 1977) equilibrated with $20 \mathrm{mM}$ sodium phosphate buffer $\mathrm{pH} 7.5$ containing $0.1 \% \quad(\mathrm{v} / \mathrm{v}) \quad \beta$ mercaptoethanol. Extract $(400 \mu \mathrm{l})$ was mixed with 400 $\mu$ l substrate solution and incubated for $3 \mathrm{~h}$ at $37^{\circ} \mathrm{C}$. Trichloroacetic acid-soluble products were determined photometrically after centrifugation (Fröhlich and Feller, 1992).

\section{SDS PAGE and immunoblotting}

Samples were prepared from the Miracloth filtrate. Since proteolysis in extracts may affect the polypeptide pattern (Des Francs et al, 1985), the samples were mixed with sample buffer immediately after extraction and boiled prior to polyacrylamide gel electrophoresis (SDS-PAGE) in a Mini Protean II Dual Slab Cell (Biorad, Richmond) according to Laemmli (1970). For visualization of total proteins, gels were stained with Coomassie brilliant blue R-250. Immunoblotting was performed according to Tijssen (1985) as described by Fröhlich and Feller (1991). All primary antibodies used were developed in the rabbit. Glutamine synthetase was detected with an antibody directed against the plastidial isoenzyme from mustard (Höpfner et al, 1988). Phosphoribulokinase (CraftsBrandner et al, 1990), nitrite reductase (Ida, 1987), ferredoxin-dependent glutamate synthase (Marquez et al, 1988), phosphoglycolate phosphatase (Baldy et al, 1989) and glycolate oxidase (Mitsuhashi and Feller, 1992) were identified on immunoblots with specific antibodies. The bands were visualized with goat-antirabbit IgG for bridging and peroxidase-anti-peroxidase soluble complex (Mitsuhashi and Feller, 1992). The peroxidase substrate was 4-chloro-1-naphthol. The entire protocol from the primary antibodies to the color reaction (followed by washing and blocking) was repeated for the detection of nitrite reductase, phosphoglycolate phosphatase and glycolate oxidase in order to amplify the bands.

\section{RESULTS}

Two low-temperature phases (November 24December 26 and January 15-February 17) were observed during winter 1990/91 (fig 1). As judged by fresh weight, plant growth was interrupted between November 28 and February 20 (fig 2). Protein and chlorophyll levels were essentially constant during this period (fig 2). In contrast, free amino groups increased by $\approx 100 \%$. Contents of buffer-soluble carbohydrates decreased later during or after the 2 marked low-temperature phases. It remains open to question whether these carbohydrates were used for anabolic processes or for respiration.

Abundant proteins can be identified on SDSPAGE gels stained with Coomassie brilliant blue (fig 3). The bands of the large and of the small subunits of Rubisco (ribulose-1,5-bisphosphate carboxylase/oxygenase) were comparable between the end of November and the end of February. The rather weak staining of the small subunit (as compared to the large subunit) can be explained by the smaller molecular weight, by the broadening of the band during running of the gel, and by the different staining properties of the 2 polypeptides. Proteins which are present in low quantities, and therefore not directly visible on Coomassie brilliant blue-stained gels, can be selectively detected on immunoblots (fig 4). The enzymes examined by this method were: phosphoribulokinase, another important enzyme of the Calvin cycle besides Rubisco; phosphoglycolate phosphatase (stromal enzyme) and glycolate oxidase (localized in peroxisomes), 2 key enzymes of the photorespiratory carbon cycle; nitrite reductase (stromal enzyme, essential for

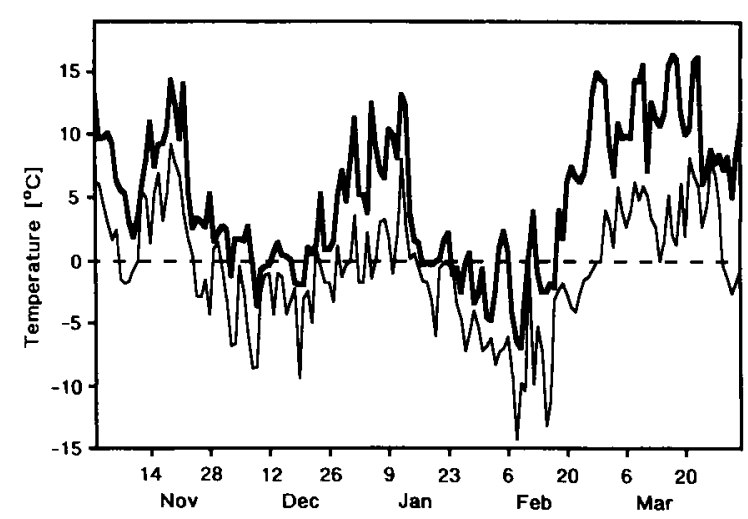

Fig 1. Daily temperature maxima (bold line) and minima (thin line) in the region of the experimental field during winter $1990 / 1991$. 

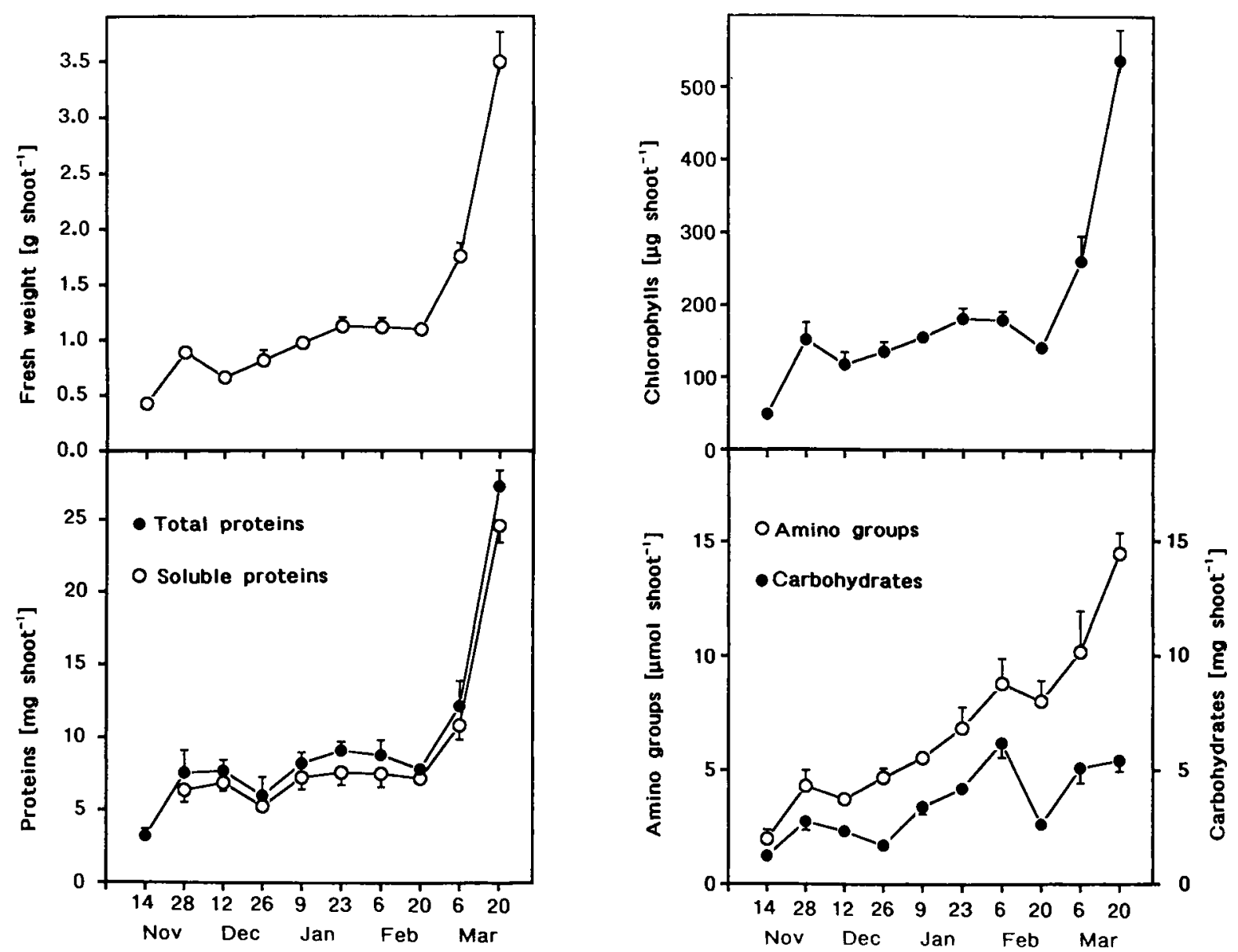

Fig 2. Nitrogen compounds and buffer-soluble carbohydrates in wheat shoots during winter 1990/1991. Means and standard deviations were computed from 4 samples (each containing 10 shoots). The standard deviations are shown when exceeding the size of the symbol (on one side only for clarity).

the assimilation of inorganic nitrate); and glutamine synthetase and ferredoxin-dependent glutamate synthase, 2 stromal enzymes involved in the assimilation of inorganic nitrate as well as in the reassimilation of ammonia liberated by catabolic processes. All these proteins, and probably also their enzymatic activities, were maintained throughout the winter (fig 4). No major decrease in level was visible on immunoblots, even during or after the marked low-temperature phases.

It has been previously reported that the peptide hydrolase pattern of wheat leaves changes markedly during development (Fröhlich and Feller, 1992). However, different proteolytic enzymes may contribute to the hydrolysis of a particular substrate, thus limiting the specificity of these assays, while the assimilatory enzymes mentioned above were detected with specific antibodies raised against purified proteins. Endopeptidase activity at pH 5.0 behaved similarly to

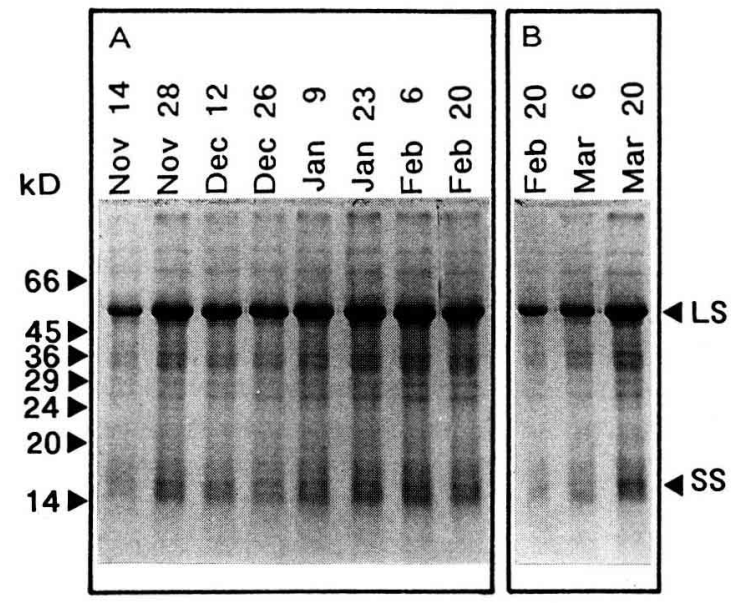

Fig 3. Pattern of total proteins in wheat shoots during winter 1990/1991. The lanes were loaded with samples mixed from 4 different extracts (each containing 10 shoots). The lanes on the left side (A) were loaded with a sample equivalent to $0.24 \%$ of a shoot, while the 3 lanes on the right side $(B)$ were loaded with a sample equivalent to $0.08 \%$ of a shoot to avoid overloading. The proteins were separated by SDS-PAGE and visualized with Coomassie brilliant blue R-250. Marker proteins are included on the left side. The arrows on the right side indicate the positions of the large (LS) and small (SS) subunits of ribulose-1,5-bisphosphate carboxylase/oxygenase. 


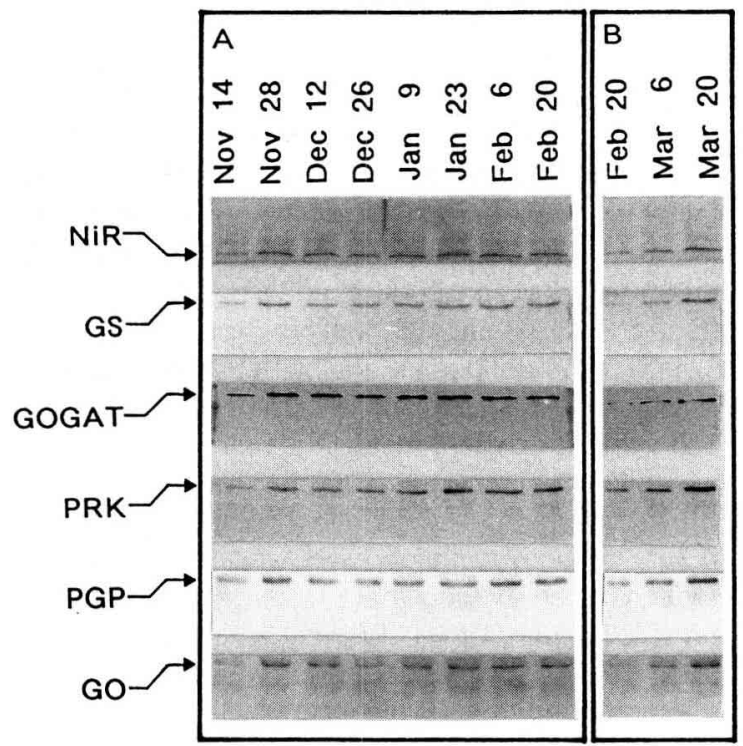

Fig 4. Immunoblots of selected enzyme proteins in wheat shoots during winter 1990/1991. The lanes were loaded with samples mixed from 4 different extracts (each containing 10 shoots). The lanes on the left side (A) were loaded with a sample equivalent to $0.36 \%$ of a shoot, while the 3 lanes on the right side $(\mathrm{B})$ were loaded with a sample equivalent to $0.12 \%$ of a shoot to avoid overloading. Nitrite reductase (NiR), glutamine synthetase (GS), glutamate synthase (GOGAT), phosphoribulokinase (PRK), phosphoglycolate phosphatase (PGP) and glycolate oxidase (GO) were detected with specific antibodies. protein contents and remained relatively constant between November 28 and February 20 (fig 5). Endopeptidase activities at $\mathrm{pH} 7.5$ and 9.0 were very low during this period. Aminopeptidase activities and carboxypeptidase activity increased during the warmer phase between December 26 and January 9. A decrease of these exopeptidase activities was detected during or after the second low-temperature phase. No drastic changes in the pattern of peptide hydrolase activities were observed during the winter.

\section{DISCUSSION AND CONCLUSION}

The quantities of assimilatory enzymes identified after SDS-PAGE and immunoblotting were essentially constant throughout the winter. The investigated enzymes were either very stable (low degradation rate) or their catabolism was compensated by de novo synthesis. The conserved assimilatory infrastructure may allow these plants to take advantage of short periods of elevated temperature during the winter and to immediately restart rapid growth in spring.
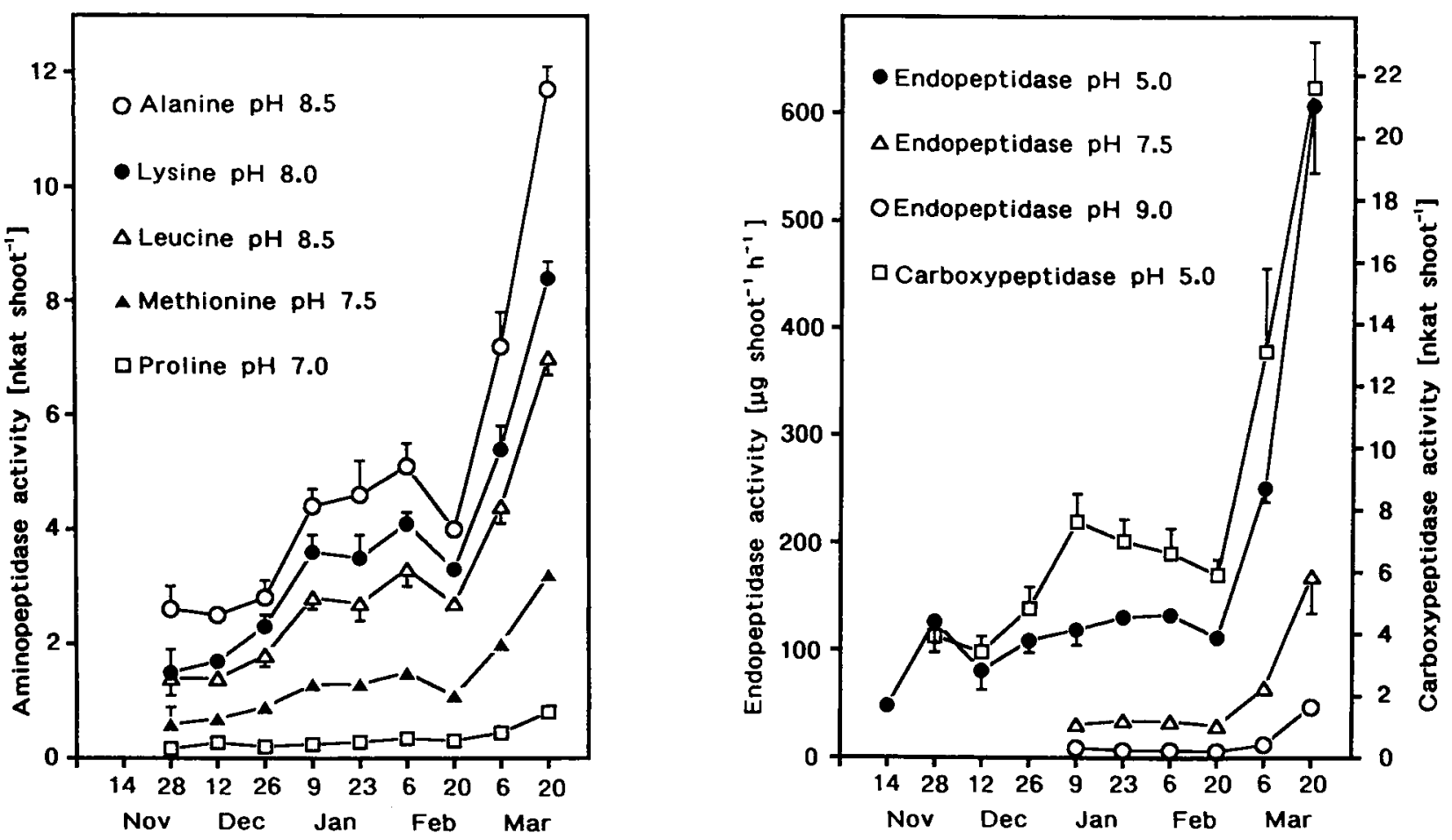

Fig 5. Peptide hydrolase activities in wheat shoots during winter 1990/1991. Aminopeptidase activities were quantified using $p$ nitroanilides of the L-amino acids indicated as substrates. Endopeptidase activities were measured with azocasein as substrate, and carboxypeptidase was detected using the $\mathrm{N}$-masked dipeptide $\mathrm{N}$-carbobenzoxy-L-phenylalanine-t-alanine. Means and standard deviations were computed from 4 samples (each containing 10 shoots). The standard deviations are shown when exceeding the size of the symbol (on one side only for clarity). 
Endopeptidase activity with a slightly acidic pH optimum and carboxypeptidase activity is located in the vacuole of cereal cells (Waters et al, 1982; Feller, 1986). Therefore, plastidial and peroxisomal enzymes are separated from these peptide hydrolases by at least 2 membranes. However, other endopeptidases have been found inside the chloroplasts (Musgrove et al, 1989), and aminopeptidases have been detected in the chloroplasts as well as outside these organelles (Waters et al, 1982; Feller, 1986). These plastidial peptide hydrolases could directly attack the stromal proteins investigated. In such situations (proteolytic enzymes and substrate proteins in the same compartment) the regulation of proteolysis becomes crucial.

It has been reported that Rubisco became less susceptible to freezing temperatures during cold hardening of winter rye plants because of structural changes (Huner and Macdowall, 1979). Chilling temperatures may alter the degree of hydration of proteins, thus leading to molecular destabilization (Frenkel, 1991). Since a frequent reason for cold inactivation is a dissociation of functional enzymes into their subunits (Guy, 1990), the activities of different enzymes could be stabilized under freezing stress by the conservation of their quartenary structures. Such reversible or irreversible effects on enzyme proteins may not only influence their enzymatic activity, but they may also alter their susceptibility to proteolysis. A denaturation or even a reversible distortion of the enzyme structure may facilitate a proteolytic attack. However, the mechanisms involved in the cold protection of enzymes are not yet satisfactorily known.

In conclusion, it was shown that several key enzymes involved in nitrogen and carbon assimilation were well conserved in the wheat variety investigated during the winter. The maintained enzymatic infrastructure may allow such vigorous plants to initiate a rapid response to a temperature rise after a cold phase, and may be beneficial for their competition with other plants. Although it is still unclear to what extent various cereal species and various genotypes within one species differ in this context, the potential to maintain assimilatory capacities under low temperatures might be relevant for genotype selection and breeding. A deeper insight into the biochemical and physiological mechanisms involved in cold tolerance may thus serve as a basis for the improvement of cold-sensitive crop plants.

\section{ACKNOWLEDGMENTS}

We thank the Landwirtschaftliche Schule Rütti in Zollikofen for supplying the plant material, $M$ Höpfner, $G$ Ochs and $A$ Wild (Johannes-Gutenberg-Universität, Mainz) for the antiserum against glutamine synthetase, SJ Crafts-Brandner (University of Kentucky, Lexington) for the antibodies against phosphoribulokinase, S Ida (Research Institute for Food Science, Kyoto) for the antibodies against nitrite reductase, RM Wallsgrove (AFRC Institute of Arable Crops Research, Rothamstead Experimental Station, Harpenden) for the antibodies against glutamate synthase, and $P$ Baldy (Université Paul Sabatier, Toulouse) for the antibodies against phosphoglycolate phosphatase, A Fleming for improving the English of the manuscript and $A$ Chanson for the French translation of the $a b$ stract. The work was supported by the Swiss National Science Foundation (Project No 31-30805.91).

\section{REFERENCES}

Andrews CJ, Pomeroy MK (1989) Metabolic acclimation to hypoxia in winter cereals. Plant Physiol 91, 1063-1068

Baldy P, Piquemal M, Cavalie G (1989) Phosphoglycolate phosphatase: immunological comparisons of the enzyme from the different photosynthetic groups of plants using maize polyclonal antiserum. Plant Sci 60, 9-20

Blättler R, Feller U (1988) Identification and stability of aminopeptidases in extracts from bean seeds. Aust J Plant Physiol 15, 613-619

Bradford MM (1976) A rapid and sensitive method for the quantification of microgram quantities of protein using the principle of protein dye binding. Anal Biochem 72, 248-254

Chen Z, Spreitzer RJ (1991) Proteolysis and transition-state-analogue binding of mutant forms of ribulose-1,5-bisphosphate carboxylase/oxygenase from Chlamydomonas reinhardtii. Planta 183, 597-603

Cloutier $Y$ (1983) Changes in the electrophoretic patterns of the soluble proteins of winter wheat and rye following cold acclimation and desiccation stress. Plant Physiol 71, 400-403

Crafts-Brandner SJ, Salvucci ME, Egli DB (1990) Changes in ribulose-bisphosphate carboxylase/ oxygenase and ribulose 5-phosphate kinase abundances and photosynthetic capacity during leaf senescence. Photosynth Res 23, 223-230

Cramer F (1958) Papierchromatographie. Verlag Chemie, Weinheim

Des Francs CC, Thiellement H, de Vienne D (1985) Analysis of leaf proteins by two-dimensional gel electrophoresis. Protease action as exemplified by ribulose bisphosphate carboxylase/oxygenase degradation and procedure to avoid proteolysis during extraction. Plant Physiol 78, 178-182 
Feller U (1986) Proteolytic enzymes in relation to leaf senescence. In: Plant Proteolytic Enzymes. Volume /l (Dalling MJ, ed) CRC Press, Boca Raton, FL, 49-68

Feller UK, Soong TST, Hageman RH (1977) Leaf proteolytic activities and senescence during grain development of field-grown corn (Zea mays L). Plant Physiol 59, 290-294

Fischer A, Salgó A, Hildbrand M, Feller U (1992) Cooperative protection of glucose-6-phosphate dehydrogenase by ligands in extracts from wheat grains. Biochem Physiol Pflanzen 188, 295-303

Fluri R (1959) Der Kohlenhydrathaushalt eines Schleimpilzes (Phycomyces blakesleanus) in Abhängigkeit von den Kulturbedingungen. Arch Microbio/ 33, 195-222

Frenkel C (1991) Disruption of macromolecular hydration - a possible origin of chilling destabilization of biopolymers. Trends Food Sci Techno/2, 39-42

Fröhlich V, Feller U (1991) Effect of phloem interruption on senescence and protein remobilization in the flag leaf of field-grown wheat. Biochem Physiol Pflanzen 187, 139-147

Fröhlich V, Feller U (1992) Effect of phloem interruption on endopeptidase and aminopeptidase activities in flag leaves of field-grown wheat. Biochem Physiol Pflanz 188, 13-21

Guy CL (1990) Cold acclimation and freezing stress tolerance: role of protein metabolism. Annu Rev Plant Physio/ 41, 187-223

Guy CL, Haskell D (1989) Preliminary characterization of high molecular mass proteins associated with cold acclimation in spinach. Plant Physiol Biochem $27,777-784$

Höpfner M, Reifferscheid G, Wild A (1988) Molecular composition of glutamine synthetase of Sinapis alba L. Z Naturforsch 43, 194-198

Houde M, Danyluk J, Lalibertė JF, Rassart E, Dhindsa RS, Sarhan F (1992) Cloning, characterization, and expression of a cDNA encoding a 50-kDa protein specifically induced by cold acclimation in wheat. Plant Physiol 99, 1381-1387

Huner NPA, Macdowall FDH (1979) The effects of low temperature acclimation of winter rye on catalytic properties of its ribulose bisphosphate carboxylaseoxygenase. Can J Biochem 57, 1036-1041
Ida S (1987) Immunological comparisons of ferredoxin-nitrite reductases from higher plants. Plant Sci $49,111-116$

Laemmli U (1970) Cleavage of structural proteins during the assembly of the head of bacteriophage T4. Nature (Lond) 227, 680-685

Marquez AJ, Avila C, Forde BG, Wallsgrove RM (1988) Ferredoxin-glutamate synthase from barley leaves: rapid purification and partial characterization. Plant Physiol Biochem 26, 645-651

Mitsuhashi W, Feller U (1992) Effects of light and external solutes on the catabolism of nuclear endoced stromal proteins in intact chloroplasts isolated from pea leaves. Plant Physiol 100, 2100-2105

Musgrove JE, Elderfield PD, Robinson C (1989) Endopeptidases in the stroma and thylakoids of pea chloroplasts. Plant Physiol 90, 1616-1621

Neven LG, Haskell DW, Guy CL, Denslow N, Klein PA, Green LG, Silverman A (1992) Association of $70-k D a$ heat-shock cognate proteins with acclimation to cold. Plant Physiol 99, 1362-1639

Perras M, Sarhan F (1989) Synthesis of freezing tolerance proteins in leaves, crown and roots during cold acclimation of wheat. Plant Physiol 89, 577585

Salgó A, Feller U (1987) Rapid micro methods for the determination of exo- and endopeptidase activities in plant extracts. Microchem J 35, 12-21

Schaffer MA, Fisher RL (1988) Analysis of mRNAs in response to low temperature identifies a thiol protease gene in tomato. Plant Physiol 87, 431-436

Steffen KL, Arora R, Palta JP (1989) Relative sensitivity of photosynthesis and respiration to freeze-thaw stress in herbaceous species. Importance of realistic freeze-thaw protocols. Plant Physiol 89, 13721379

Strain HH, Cope BT, Svec WA (1971) Analytical procedures for the identification, estimation and investigation of the chlorophylls. In: Methods in Enzymology 23 (Sanpietro A, ed) Academic Press Inc, NY, 452-487

Tijssen $P$ (1985) Practice and Theory of Enzyme $\mathrm{Im}$ munoassays. Elsevier Sci Publ, Amsterdam

Waters SP, Noble ER, Dalling MJ (1982) Intracellular localization of peptide hydrolases in wheat (Triticum aestivum L) leaves. Plant Physiol 69, 575-579 